Dhaka Univ. J. Biol. Sci. 28(1): 1-7, 2019 (January)

\title{
ANTAGONISTIC POTENTIALS OF SOME SOIL FUNGI AGAINST THREE POST-HARVEST PATHOGENIC FUNGI OF CARICA PAPAYA L.
}

\author{
Rezuana Binte Helal ${ }^{1}$ and Shamim Shamsi* \\ Department of Botany, University of Dhaka, Dhaka-1000, Bangladesh
}

Key words: Antagonistic potentiality, Soil fungi, Pathogenic fungi, Diseased fruits, Carica papaya

\begin{abstract}
Four antagonistic fungi were isolated from the papaya field soil by serial dilution and were identified as Aspergillus flavus Link., A. fumigatus Fresenius, $A$. niger van Tiegh. and Trichoderma viride Pers. The soil fungi were selected to evaluate their antagonistic potentiality against the three postharvest pathogenic fungi of Carica papaya L. following "dual culture colony interaction" and volatile and non-volatile metabolites. In dual culture colony interaction, out of four soil fungi, $T$. viride showed the highest growth inhibition on C. gloeosporioides $(84.28 \%)$, F. nivale $(95.23 \%)$ and Fusarium sp. (87.15\%). On the other hand A. niger showed the highest growth inhibition on C. gloeosporioides (77.39\%), F. nivale $(98.63 \%)$ and Fusarium sp. (35.05\%). The maximum inhibition of radial growth of C. gloeosporioides $(77.64 \%)$, F. nivale $(58.76 \%)$ and Fusarium sp. $(79.37 \%)$. were observed in case of $T$. viride owing to the volatile metabolites. Whereas the maximum inhibition of radial growth of C. gloeosporioides (58.23\%), F. nivale (37.43\%) and Fusarium sp. (82.31\%) were observed in case of A. niger owing to the volatile metabolites. The maximum inhibition of radial growth of $C$. gloeosporioides $(90.90 \%)$, F. nivale $(89.13 \%)$ and Fusarium sp. (76.84\%) were observed in case of $T$. viride owing to the effect of non-volatile metabolites. The maximum inhibition of radial growth of C. gloeosporioides (92.42\%), F. nivale (73.01\%) and Fusarium sp. (68.67\%) were observed in case of A. niger owing to the effect of non-volatile metabolites. Trichoderma viride and A. niger may be exploited commercially as a biocontrol agent against anthracnose and fruit rot pathogens of papaya.
\end{abstract}

\section{Introduction}

Papaya (Carica papaya L.) is one of the most popular fruits of the world belongs to the family "Caricaceae"(1). In Bangladesh, total estimated production of papaya is 133370

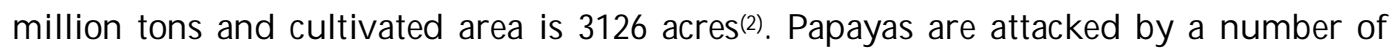
pathogens from bloom to harvest and in storage which cause considerably deteriorate the fruit quality (3). It is estimated that about $20-25 \%$ of the harvested papaya fruits are decayed by pathogens during postharvest handling even in developed countries ${ }^{(4-5)}$. Approximately $39.9 \%$ post-harvest losses of papaya fruits were estimated in Bangladesh and the value stands for that is Tk. 132.91 crore $^{(6)}$.

*Author for correspondence: <prof.shamsi@gmail.com>. ${ }^{1} \mathrm{~A}$ part of MS thesis of first author (RBH). 
Over the past few decades, farmers have increasingly relied on chemical pesticides for protecting plants against pathogens. However, the increasing use of chemical pesticides negatively affects the environment and human health. Biological control of plant diseases including fungal pathogens has been considered a viable alternative method to chemical control. Biological control presents a better alternative with relative low cost, without any side effects ${ }^{(7-8)}$.

Study of antagonist as biological control agent has now become one of the most exciting and rapidly developing areas in plant pathology because it has great potential to solve many agricultural and environmental problems. At present, Trichoderma-based products are considered as relatively novel biological control agents which can help farmers to reduce plant diseases and increase plant growth ${ }^{(9)}$.

In Bangladesh, research on biological control of postharvest diseases of papaya fruits is very limited and considering the importance of this popular fruits present investigation was undertaken to find out the biological efficacy as antagonist of the selected soil fungi against the pathogens of postharvest diseases of papaya.

\section{Materials and Methods}

Nineteen species of fungi were isolated from infected Shahi papaya during April to November, 2016. Among the isolated fungi three were found to be pathogenic to papaya fruits. The pathogenic fungi were C. gloeosporioides, F. nivale and Fusarium sp. These three fungi were selected as test pathogen against selected four antagonistic fungi.

Serial dilution method was used to isolate antagonistic fungi from rhizosphere soil of the host varieties. Among the isolated soil fungi, Aspergillus flavus, A. fumigatus, A. niger and Trichoderma viride were selected to test their antagonistic potential against the pathogens following dual culture technique ${ }^{(10)}$. Aforesaid fungi were previously tested on fungal isolates obtained from Musa sp. and found effective against the test fungi. The parameter used for the assessment of the colony interaction and per cent inhibition of radial growth was calculated (11). Effects of volatile and non-volatile metabolites of the selected soil fungi against the test pathogens were also studied(12). The results were statistically analyzed by $t$ test ${ }^{(13)}$.

\section{Results and Discussion}

The results of colony interactions have been summarized in Table 1 and Fig. 1. In this study, antagonistic relationships (Grade) among the soil fungi and test pathogens were 2 and 4 . However, grade 2 was found to be the most commonly encountered type of colony interaction as 10 interactions were incorporated in this grade which was followed by grade 4 ( 2 out of 12 ) (Table 1$)$. 
In dual culture colony interaction Trichoderma viride showed the highest growth inhibition on Colletotrichum gloeosporioides (84.28\%) which was followed by Aspergillus niger (77.39\%), A. flavus (43.71\%) and A. fumigatus (29.32\%) (Fig. 1). Aspergillus niger (98.63\%) showed the highest growth inhibition on Fusarium nivale which was followed by Trichoderma viride $(95.23 \%)$, A. flavus $(74.70 \%)$, and A. fumigatus $(32.94 \%)$. Trichoderma viride showed the highest (87.15\%) growth inhibition on Fusarium sp. which was followed by A. fumigatus (55.27\%), A. flavus (48.66\%) and A. niger (35.05\%).

Table 1. Grades of colony interaction between the test pathogens and antagonists.

\begin{tabular}{lccc}
\hline \multirow{2}{*}{$\begin{array}{l}\text { Name of } \\
\text { antagonists }\end{array}$} & \multicolumn{3}{c}{ Name of test pathogens } \\
\cline { 2 - 4 } & Colletotrichum gloeosporioides & Fusarium nivale & Fusarium sp. \\
\hline Aspergillus flavas & 2 & 2 & 2 \\
A. fumigatus & 4 & 2 & 2 \\
A. niger & 2 & 2 & 2 \\
Trichoderma viride & 2 & 2 & 4 \\
\hline
\end{tabular}

Grade 2 = Mutual intermingling growth where the growth of the fungus is ceased and being over growth by the opposed fungus. Grade $4=$ Slight inhibition of both the interacting fungi with narrow demarcation line (1 - $2 \mathrm{~mm}$ ) based on Skidmore and Dickinson (1976) $)^{(11)}$.

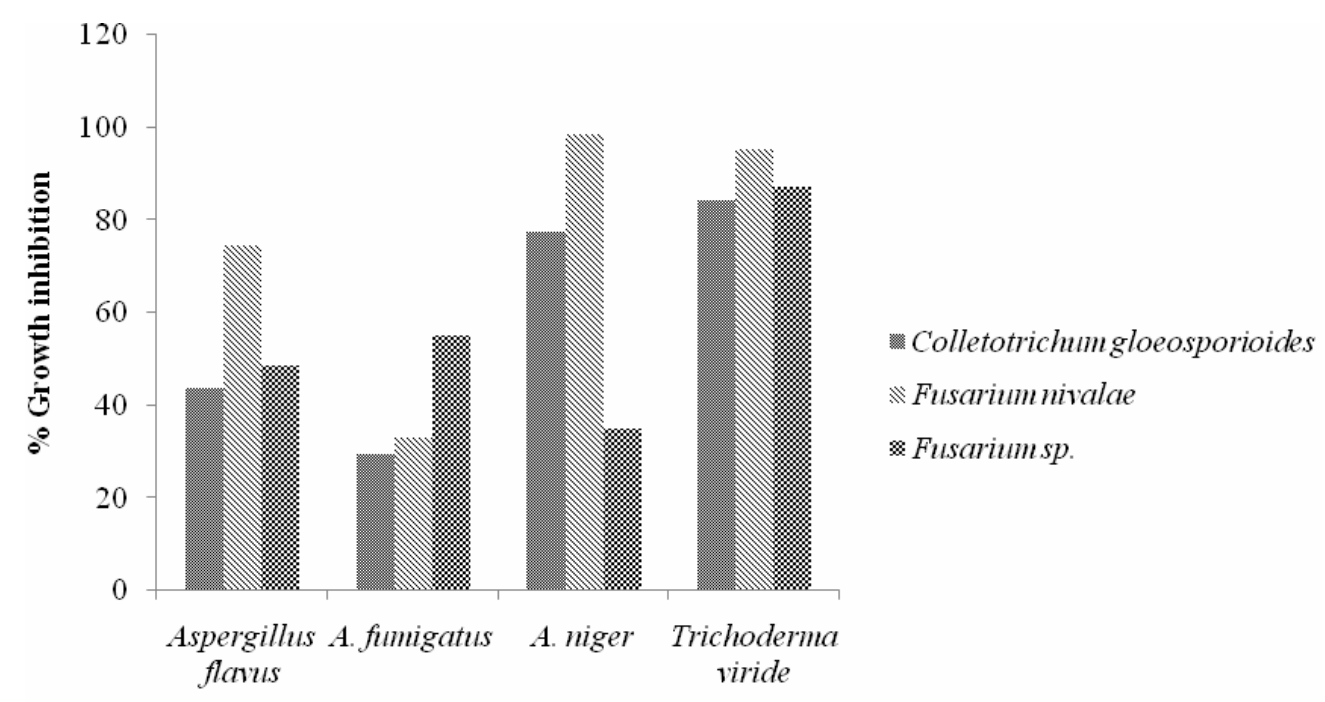

Antagonists

Fig.1. Per cent inhibition of Colletotrichum gloeosporioides, Fusarium nivale and Fusarium sp. owing to fungal antagonists (in dual culture).

In contrast to the present study, Akter et al.(14) reported that in dual culture colony interaction Aspergillus niger, Trichoderma viride, A. flavus and A. fumigaus showed 68.66, 
57.24, 54.19 and $50.25 \%$ growth inhibition on Colletotrichum sp., respectively. Again Aspergillus niger, Trichoderma viride, A. flavus and A. fumigaus showed 75.87, 75.5, 51.78 and $45.52 \%$ growth inhibition on Curvularia lunata, respectively. Further Trichoderma viride, Aspergillus niger, A. flavus and A. fumigaus showed 56.52, 50.70, 47.36 and 46.15\% growth inhibition on Fusarium semitectum, respectively. Bashar and Chakma ${ }^{(15)}$ reported that in dual culture colony interaction A. niger, T. viride, A. flavus and A. fumigatus showed $65.21,64.24,57.14$ and $34.78 \%$ growth inhibition on $F$. oxysporum, respectively. Tapwal et al (16) reported that in dual culture colony interaction T. viride showed $12.50 \%$ growth inhibition on C. gloeosporioides. This variation might be due to selection of different test pathogens. In dual culture technique, significantly maximum inhibition was recorded in T. viride (66.40\%) according to Patel and Joshi ${ }^{(17)}$.

The results of effect of volatile metabolites of antagonistic fungi against papaya pathogens are presented in Table 2. The maximum inhibition of radial growth of Colletotrichum gloeosporioides was observed in Trichoderma viride $(77.64 \%)$ which was followed by Aspergillus flavus (75.58\%), A. fumigatus (60.88\%) and A. niger (58.23\%) due to the volatile metabolites after 6 days of incubation at $25 \pm 2^{\circ} \mathrm{C}$. The maximum inhibition of radial growth of Fusarium nivale was also observed in Trichoderma viride (58.76\%) followed by Aspergillus fumigatus (48.34\%), A. niger (37.43\%) and A. flavus (34.40\%) owing to the volatile metabolites after 6 days of incubation at the same temperature. The maximum inhibition of radial growth of Fusarium sp. was observed in Aspergillus niger (82.31\%) which was followed by Trichoderma viride (79.37\%), A. flavus (46.56\%) and A. fumigatus (34.37\%) owing to the volatile metabolites after 6 days of incubation at $25 \pm 2^{\circ} \mathrm{C}$.

Table 2. Per cent inhibition of radial growth of the test pathogens by volatile metabolites of antagonistic fungi.

\begin{tabular}{lccc}
\hline \multirow{2}{*}{$\begin{array}{l}\text { Name of } \\
\text { antagonist }\end{array}$} & \multicolumn{2}{c}{ \% inhibition of radial growth of the test pathogens } \\
\cline { 2 - 4 } & Colletrotrichum gloeosporioides. & Fusarium nivale & Fusarium sp. \\
\hline Aspergillus flavus & $75.58^{\mathrm{a}}$ & $34.40^{\mathrm{c}}$ & $46.56^{\mathrm{b}}$ \\
A. fumigatus & $60.88^{\mathrm{b}}$ & $48.34^{\mathrm{c}}$ & $34.37^{\mathrm{c}}$ \\
A. niger & $58.23^{\mathrm{b}}$ & $37.43^{\mathrm{c}}$ & $82.31^{\mathrm{a}}$ \\
Trichoderma viride & $77.64^{\mathrm{a}}$ & $58.76^{\mathrm{b}}$ & $79.37^{\mathrm{a}}$ \\
\hline
\end{tabular}

$\mathrm{a}$ and $\mathrm{b}$ indicate significance of ' $\mathrm{t}$ 'value at $\mathrm{p}=0.001$ and 0.01 , respectively.

In contrast to the present study, Aktar et al.(14) reported that volatile metabolites produced by an isolate of Aspergillus niger, A. flavus, A. fumigatus and Trichoderma viride inhibited the mycelial growth of Colletotrichum sp. by 14.68, 11.78, 11 and 11\%, respectively. Further the volatile metabolites produced by an isolate of Trichoderma viride, Aspergillus niger, A. flavus and A. fumigatus inhibited the mycelial growth of Fusarium 
semitectum by $13.5,9.5,8$ and $7.75 \%$, respectively. Differences in per cent inhibition with the present study might be due to the difference in organism involved in the interaction. Bashar and Chakma ${ }^{(15)}$ reported that volatile substances produced by T. viride, A. niger, A. flavus and A. fumigates showed 29.75, 20.15, 15.78 and $12.25 \%$ growth inhibition on $F$. oxysporum, respectively. Thakur and Harsh ${ }^{(18)}$ reported that volatile metabolites produced from the culture of Aspergillus niger showed $42.43 \%$ inhibition of mycelial growth of $C$. gloeosporioides.

Table 3 shows the effect of non-volatile metabolites on the growth of Colletotrichum gloeosporioides, Fusarium nivale and Fusarium sp. The maximum inhibition of radial growth of Colletotrichum gloeosporioides was observed with the culture filtrates of A. flavus (92.42\%), which was followed by T. viride (90.90\%), A. niger (86.13\%) and A. fumigatus

Table 3. Per cent inhibition of radial growth of test pathogens by non-volatile metabolites of antagonistic fungi.

\begin{tabular}{|c|c|c|c|c|c|}
\hline \multirow[t]{2}{*}{$\begin{array}{l}\text { Name of } \\
\text { fungi }\end{array}$} & \multirow[t]{2}{*}{$\begin{array}{c}\text { Concentration } \\
(\%)\end{array}$} & \multicolumn{4}{|c|}{$\begin{array}{c}\text { \% inhibition of radial growth of test pathogens by } \\
\text { non-volatile metabolites owing to different } \\
\text { antagonists }\end{array}$} \\
\hline & & $\begin{array}{l}\text { Aspergillus } \\
\text { flavus }\end{array}$ & $\begin{array}{c}\text { A. } \\
\text { fumigatus }\end{array}$ & $\begin{array}{c}\text { A. } \\
\text { niger }\end{array}$ & $\begin{array}{c}\text { Trichoderma } \\
\text { viride }\end{array}$ \\
\hline Colletotrichum & 5 & $60.20^{a}$ & $49.49^{a}$ & $62.37^{a}$ & $67.81^{\mathrm{a}}$ \\
\hline \multirow[t]{3}{*}{ gloeosporioides } & 10 & $70.72^{\mathrm{a}}$ & $59.59^{a}$ & $74.25^{\mathrm{a}}$ & $74.09^{a}$ \\
\hline & 15 & $85.14^{\mathrm{a}}$ & $69.69^{a}$ & $78.20^{\mathrm{a}}$ & $82.18^{a}$ \\
\hline & 20 & $92.42^{\mathrm{a}}$ & $73.73^{\mathrm{a}}$ & $86.13^{a}$ & $90.90^{\mathrm{a}}$ \\
\hline \multirow[t]{4}{*}{ Fusarium nivale } & 5 & $49.25^{b}$ & $40.25^{b}$ & $53.19^{b}$ & $58.69^{b}$ \\
\hline & 10 & $52.22^{\mathrm{a}}$ & $44.15^{b}$ & $66.38^{b}$ & $78.26^{\mathrm{a}}$ \\
\hline & 15 & $67.61^{a}$ & $64.93^{a}$ & $73.19^{a}$ & $80.43^{a}$ \\
\hline & 20 & $73.01^{a}$ & $71.42^{\mathrm{a}}$ & $77.65^{\mathrm{a}}$ & $89.13^{\mathrm{a}}$ \\
\hline \multirow[t]{4}{*}{ Fusarium sp. } & 5 & $51.80^{\mathrm{a}}$ & $42.85^{\mathrm{b}}$ & $33.82^{b}$ & $58.77^{b}$ \\
\hline & 10 & $59.03^{\mathrm{a}}$ & $50.01^{\mathrm{a}}$ & $35.29^{b}$ & $72.00^{\mathrm{a}}$ \\
\hline & 15 & $61.44^{\mathrm{a}}$ & $61.90^{\mathrm{a}}$ & $64.70^{\mathrm{a}}$ & $72.63^{\mathrm{a}}$ \\
\hline & 20 & $68.67^{a}$ & $66.66^{a}$ & $70.78^{a}$ & $76.84^{a}$ \\
\hline
\end{tabular}

a and $\mathrm{b}$ indicate significance of ' $\mathrm{t}$ 'value at $\mathrm{p}=0.001$ and 0.01 , respectively.

(73.73\%) at $20 \%$ concentration. The maximum inhibition of radial growth of Fusarium nivale was observed with the culture filtrates of Trichoderma viride $(89.13 \%)$ which was followed by A. niger (77.64\%), A. flavus (73.01\%), and A. fumigatus $(71.42 \%)$ at $20 \%$ concentration. The maximum inhibition of radial growth of Fusarium sp. was observed with the culture filtrates of $T$. viride $(76.84 \%)$ which was followed by $A$. niger $(70.58 \%), A$. flavus (68.67\%) and A. fumigatus (66.66\%) at $20 \%$ concentration. 
In contrast to the present study, Aktar et al.(14) reported that non-volatile metabolites produced by an isolate of Aspergillus niger, Trichoderma viride, A. flavus and A. fumigatus inhibited mycelial growth of Colletotrichum sp. by 52.56, 44.72, 40 and $37.2 \%$, respectively. Further, the non-volatile metabolites produced by an isolate of Trichoderma viride, Aspergillus niger, A. flavus and A. fumigatus inhibited mycelial growth of Fusarium semitectum by $50,45,8$ and $7.75 \%$, respectively. Differences in per cent inhibition with the present study might be due to the difference in organism strain involved in the interaction. Bashar and Chakma ${ }^{(15)}$ reported that culture filtrates of T. viride, A. fumigatus, $A$. niger and A. flavus showed 82.05, 80.56, 72.22 and $66.66 \%$ growth inhibition of $F$. oxysporum at $20 \%$ concentration owing to non-volatile metabolites. Madhanraj et al.(19) reported that culture filtrates of $T$. viride and $A$. niger inhibited the mycelial growth of $F$. solani by 85 and $70 \%$ at 20 per cent concentration, respectively. Tran ${ }^{(9)}$ used T. viride to control S. rolfsii and found effective result. Tapwal et al.(16) reported that culture filtrates of T. viride showed $13.33 \%$ growth inhibition on C. gloeosporioides.

The present investigation suggests that Trichoderma viride and Aspergillus niger may be exploited commercially as a biocontrol agent to protect postharvest decay of papaya fruits belongs to Carica papaya.

\section{Acknowledgement}

The first author (RBH) wishes to expresses her gratitude to the Ministry of Science and Technology, People's Republic of Bangladesh for providing financial assistance to this research work through NST fellowship program.

\section{References}

1. Ahmed ZU, Hasan MA, Begum ZNT and Khondker M, kabir SMH, Ahmed M, Ahmed ATA, Rahman AKA and Haque EU (eds.) 2008. Encyclopedia of Flora and Fauna of Bangladesh, Vol. 7. Angiosperms: Dicotyledons (Balsaminaceae- Euphorbiaceae). Asiatic Society of Bangladesh, Dhaka. pp. 546.

2. Anonymous 2015. Statistical Yearbook of Bangladesh. 27th series, Statistics and Informatics Division, Ministry of Planning, Govt. of the People's Republic of Bangladesh, Dhaka. pp.117.

3. Ploetz RC, Zentmyer GA, Nishizima WT, Rohrbach KG and Ohr HD 1994. Compendium of Tropical Fruit Diseases, APS press. pp. 34-41.

4. Droby S. 2006. Improving quality and safety of fresh fruits and vegetables after harvest by the use of biocontrol agents and natural materials. Acta Horticul. 709: 45-51.

5. Zhu SJ. 2006. Non-chemical approaches to decay control in postharvest fruit. In: Noureddine B Norio S, editors. Advances in postharvest technologies for horticultural crops. Trivandrum: Research Signpost. p. 297-313.

6. Hassan MK 2010. A guide to postharvest handling of fruits and vegetables, Department of Horticulture. Bangladesh Agricultural University, Mymensingh. I-XV + 117 . 
7. Okigbo RN and Ikediugwu FEO 2000. Studies on Biological control of post-harvest rot of yams (Dioscorea spp.) with Trichoderma viride. J . Phytropathol. 148: 351.

8. Okigbo RN and Nmeka IA 2005. Control of yam tuber rot with leaf extracts of Xylopia aethiopics and Zingiber officinals. Afri. J. Biotechnol. 4(8): 804-807.

9. Tran N Ha 2010. Using Trichoderma species for biological control of plantpathogens in Viet Nam. J. ISSAAS 16(1): 17-21.

10. Fokkema NJ 1976. Antagonism between fungal saprophytes and pathogens on aerial plant surfaces. In: Microbiology of Aerial Plant Surfaces (eds Dickinson $\mathrm{CH}$ and Preece TF), Academic Press, London. pp. 487-505.

11. Skidmore AM and Dickinson CH 1976. Colony interaction and hyphal interference between Septoria nodorum and phylloplane fungi. Trans. Brit. Mycol. Soc. 66: 57-64.

12. Bashar MA and Rai B 1994. Antagonistic potential of root-region microflora of chickpea against Fusarium oxysporum f. sp. ciceri. Bangladesh J. Bot. 23(1): 13-19.

13. Steel RGD and Torrie JH 1960. Principles and Procedures of Statistics. MacGraw Hill Book Co., New York. pp. xvi +481 .

14. Aktar MT, Hossain KS and Bashar MA 2014. Antagonistic potential of rhizosphere fungi against leaf spot and fruit rot pathogens of brinjal. Bangladesh J. Bot. 43(2): 213-217.

15. Bashar MA and Chakma M 2014. In vitro control of Fusarium solani and F. oxysporum the causative agent of brinjal wilt. Dhaka Univ. J. Biol. Sci. 23(1): 53-60.

16. Thapwal A, Tyagi A, Thakur G and Chandra S 2015. In vitro evaluation of Trichoderma species against seed borne pathogens. IJCBS research paper 1(10).

17. Patel KD and Joshi KR 2001. Antogonistic effect of some bioagents in vitro against Colletotrichum gloeosporioides Penz. and Sacc. the causal agent of leaf spot of turmeric. J. Mycol. and Pl. Path. 31: 126.

18. Thakur S and Harsh NSK 2014. In vitro potential of volatile metabolites of phylloplane fungi of Piper longumus biocontrol against plant pathogens. I.J.S.N. 5(1): 33-36.

19. Madhanraj P, Ambikapathy V and Panneerselvam A 2010. Biological control of banana wilt caused by Fusarium solani (Mart.) Sacc. International Journal of Applied Biology and Pharmaceutical Technology 1(3): 1032-1039.

(Manuscript received on 15 March, 2018; revised on 8 May, 2018) 